\title{
Adoption Reverses the Long-Term Impairment in Glucocorticoid Feedback Induced by Prenatal Stress
}

\author{
Stefania Maccari, Pier Vincenzo Piazza, Mohamed Kabbaj, Arnaud Barbazanges, Hervé Simon, and \\ Michel Le Moal \\ Psychobiologie des Comportements Adaptatifs, INSERM U. 259, Université de Bordeaux II, Domaine de Carreire, 33077 \\ Bordeaux France
}

The development of the organism is subjected to critical and complex influences during the perinatal period. Prenatal and postnatal stresses can have different long-term behavioral effects, and appropriate postnatal manipulations can counteract the behavioral effects of prenatal stress. In the present study, we investigated the involvement of changes in the activity of the hypothalamo-pituitary-adrenal (HPA) axis in the long-term effects of prenatal and postnatal events and of interactions between them. We investigated stress-induced corticosterone secretion and hippocampal corticosteroid receptors in male adult rats submitted to prenatal and/or postnatal manipulations. Repeated restraint during the last week of pregnancy was used as prenatal stressor, and adoption at birth was used to change the postnatal environment. We found that (1) prenatal stress prolongs stressinduced corticosterone secretion in adult rats, which was attributed to the observed decrease in central corticosteroid receptors; (2) adoption, irrespective of the stress experience of the foster mother, reverses the effects of prenatal stress; and (3) adoption per se increases maternal behavior and decreases the stress-induced corticosterone secretion peak in the adult offspring. In conclusion, certain prenatal and postnatal manipulations appear to have opposite long-term effects on the activity of the HPA axis, and adoption, probably by modifying maternal behavior, can protect against the effects of prenatal stress. Thus, changes in the activity of the HPA axis may be one of the biological substrates of the long-term effects of certain perinatal events.

[Key words: corticosterone, corticosteroid receptors, hippocampus, prenatal stress, adoption, postnatal stress, perinatal environment]

Prenatal and postnatal environments exercise complex influences on the development of an organism. In particular, life events occurring during these two early periods of life can have different long-term behavioral effects. For example, in man, prenatal stress can induce mental retardation and sleep distur-

\footnotetext{
Received Feb. 3, 1994; revised Apr. 18, 1994; accepted May 19, 1994.

This study was supported by the Institut National de la Santé et de la Recherche Médicale (INSERM), the Université de Bordeaux II, the Conseil Régional d'Aquitaine. We thank Roussel-UCLAF for providing RU 28362 and Dr. Chantal Henry for valuable technical assistance.

Correspondence should be addressed to Stefania Maccari, Ph.D., INSERM U259, Université de Bordeaux II, Rue Camille Saint Saëns, 33077 Bordeaux Cedex, France.

Copyright (C) 1995 Society for Neuroscience $0270-6474 / 95 / 150110-07 \$ 05.00 / 0$
}

bances in the infant (Stott, 1973; Shell, 1981). In animals, dams stressed during pregnancy can bear offspring with reduced male sexual activity, enhanced emotional reactivity (Thompson, 1957; Ward and Weisz, 1984; Weinstock et al., 1988), and an increased propensity to self-administer drugs (Deminière et al., 1992). Conversely, postnatal stimulation has been found to improve the performance of adult and aged offspring in cognitive tasks (Meaney et al., 1988). Although prenatal and postnatal events can have different behavioral consequences, they may also impinge on the same behavioral response, and postnatal manipulations can reverse the behavioral effects of prenatal stress. For example, it has been shown that postnatal handling can reverse the increase in emotional reactivity induced by prenatal stress (Wakshlak and Weinstock, 1990).

Several observations indicate that glucocorticoid secretion could be a substrate of the different long-term behavioral effects of prenatal and postnatal events. First, prenatal stress increases the stress-induced corticosterone secretion peak in preweaning rats (Peters, 1982; Takahashi et al., 1988) and attenuates its habituation over repeated exposure to stress in the adult (Fride et al., 1986). Second, postnatal handling reduces stress-induced corticosterone secretion in adult and aged individuals, probably by strengthening corticosterone feedback (Levine, 1962; Meaney et al., 1988). Third, impairment in glucocorticoid feedback, resulting in an increased glucocorticoid secretion, is associated with behavioral disorders in adult (Persky, 1975; Pepper and Krieger, 1984; Holsboer, 1989) and aged individuals (McEwen et al., 1986; Sapolsky et al., 1986). In addition, an increase in glucocorticoid levels can induce behavioral disturbances in humans (Hall et al., 1979; Ling et al., 1981) and enhance the addictive properties of drugs in animals (Piazza et al., 1991).

In the present study, we examined the influence of prenatal and postnatal experiences on the activity of the hypothalamopituitary-adrenal (HPA) axis. We attempted to address two main questions. First, what are the mechanisms involved in the deregulation of corticosterone secretion in prenatally stressed, adult rats? Second, is the HPA axis a biological substrate for the interaction between postnatal and prenatal events?

We thus assessed stress-induced corticosterone secretion and hippocampal corticosteroid receptors in adult rats that had been submitted to prenatal and/or postnatal manipulations. Repeated restraint of the mother during the last week of pregnancy was used as prenatal stressor, while adoption at birth was employed to change the postnatal environment. Hippocampal corticosteroid receptors were determined as the binding capacity of these receptors appears to be a principal regulating factor in corticosterone secretion. A decrease in these receptors is accompa- 
nied by an increase in glucocorticoid secretion and vice versa (McEwen et al., 1986; De Kloet and Reul, 1987). Two different cytosolic receptors for adrenal steroids (Hollenberg et al., 1985; Arriza et al., 1987) contribute to this control (Ratka et al., 1989), namely, (1) the type I or mineralocorticoid receptor, and (2) the type II or glucocorticoid receptor (Reul and de Kloet, 1985).

Our results show that (1) prenatal stress decreases central corticosteroid receptors, and prolongs stress-induced corticosterone secretion in adult male rats; (2) adoption at birth, independently by the stress experience of the foster mother, reverses the effects of prenatal stress; and (3) adoption per se modifies maternal behavior, increasing pup-directed behavior in foster mothers, and decreases the stress-induced corticosterone secretion peak in the adult offspring.

\section{Materials and Methods}

\section{General methods}

Subjects. Virgin female Wistar rats weighing $250 \mathrm{gm}$ were housed for 5 $d$ in the presence of a sexually experienced male Wistar rat weighing $400 \mathrm{gm}$. At the end of this period, the pregnant females were randomly assigned to prenatal stress and control groups, and were then individually housed with ad libitum access to food and water. A constant light/ dark cycle (on at $06: 00 \mathrm{hr}$, off at 20:00 hr) was maintained in the animal house, and temperature $\left(22^{\circ} \mathrm{C}\right)$ and humidity $(60 \%)$ were kept constant.

Prenatal stress and adoption procedures. Pregnant female rats were divided into two groups. One group served as a control and was left undisturbed in the home cage; the other group was submitted to restraint stress as described by Ward and Weisz (1984). Briefly, pregnant females were placed individually in a plastic transparent cylinder $(6 \mathrm{~cm}$ diameter, $20 \mathrm{~cm} \mathrm{long}$ ) for three $45 \mathrm{~min}$ periods per day ( 9 and 12 A.M. and 5 P.M.) between the 14 th and the 21 st days of pregnancy. The sessions were performed in a lighted environment. This stress procedure was chosen as it has an indirect influence on the fetus via a direct stress on the mother. At birth, half the pups were raised by their biological mother and the other half were assigned to either control or prenatally stressed foster mothers. The pups were placed in the cage of the adoptive mother within the first 3-6 hr after birth. During this procedure, the mothers were briefly (less than $1 \mathrm{~min}$ ) removed from their cages. The offspring were weaned $21 \mathrm{~d}$ after birth, and left undisturbed until testing at $90 \mathrm{~d}$ of age. No more than three male siblings per litter were tested in adult life.

Corticosterone assay. In the first experiment, corticosterone levels were determined by radioimmunoassay using a highly specific corticosterone antiserum (Kit ICN Biomedicals Inc.). In the second experiment, plasma corticosterone levels were determined by radiocompetitive binding (Murphy, 1967).

Type I and type II corticosteroid receptor binding. In order to eliminate endogenous corticosterone, an exchange assay was used for both type I and type II corticosteroid receptors as previously described (Casolini et al., 1993). The hippocampus of each ral was homogenized in 2 ml of ice-cold $30 \mathrm{~mm}$ Tris (TEDGM; pH adjusted to 7.4 with $6 \mathrm{~N} \mathrm{HCl}$ ) containing 1 mм EDTA, $10 \mathrm{~mm}$ sodium molybdate, $1 \mathrm{~mm}$ dithiothreitol, and $10 \%$ glycerol, and centrifuged $(105,000 \times \mathrm{g}, 15 \mathrm{~min}$ in a Beckman TL100 ultracentrifuge) at $4^{\circ} \mathrm{C}$. Endogenous, unbound steroids were removed from the soluble fraction by passing the sample through LH-20 columns filled using Pasteur pipette tips and equilibrated with TEGM buffer ( $10 \mathrm{~mm}$ Tris, $2 \mathrm{~mm}$ EDTA, $10 \mathrm{~mm}$ sodium molybdate, and 2.3 mм $\beta$-mercaptoethanol). For the type I receptor assay, aliquots of cytosol $(140 \mu \mathrm{l})$ were incubated with tritiated corticosterone $\left({ }^{3} \mathrm{H}-\mathrm{B}\right.$; specific activity, $88 \mathrm{Ci} / \mathrm{mmol}$; New England Nuclear) over a concentration range of 1.25-40 nm (six points for each Scatchard plot) and with a 100-fold excess of unlabeled RU 28362. Unlabeled RU 28362 was used to displace ${ }^{3} \mathrm{H}$-B from type II receptors. Type II receptor binding was evaluated directly using the pure glucocorticoid ${ }^{3} \mathrm{H}-\mathrm{RU} 28362$ (specific activity, $74.3 \mathrm{Ci} / \mathrm{mmol}$; Dositek) over a concentration range of $1.25-40$ nM (six points for each Scatchard plot). Nonspecific binding (NSB) for ${ }^{3} \mathrm{H}-\mathrm{B}$ was determined in the presence of a 500 -fold excess of unlabeled corticosterone, and for ${ }^{3} \mathrm{H}-\mathrm{RU} 28362$ in the presence of a 500 -fold excess of unlabeled RU 28362. Binding equilibrium was reached after $22 \mathrm{hr}$ at $4^{\circ} \mathrm{C}$. This has been shown to be sufficient for maximal exchange, and binding remains stable over this period (Kalimi and Hubbard, 1983;
Table 1. Experimental groups

\begin{tabular}{|c|c|c|c|}
\hline \multirow[b]{2}{*}{ Groups } & \multirow[b]{2}{*}{ Prenatal stress } & \multicolumn{2}{|c|}{ Adoption } \\
\hline & & $\begin{array}{l}\text { Control } \\
\text { mother }\end{array}$ & $\begin{array}{l}\text { Stressed } \\
\text { mother }\end{array}$ \\
\hline $\mathrm{C}$ & - & - & - \\
\hline $\mathbf{S}$ & $\mathrm{X}$ & - & - \\
\hline $\mathrm{CC}$ & - & $\mathrm{X}$ & - \\
\hline SS & $\mathrm{X}$ & - & $\mathrm{X}$ \\
\hline $\mathrm{CS}$ & - & - & $\mathrm{x}$ \\
\hline $\mathrm{SC}$ & $\mathrm{X}$ & $\mathrm{X}$ & - \\
\hline
\end{tabular}

Meaney et al., 1988). Bound and unbound ${ }^{3} \mathrm{H}-\mathrm{B}$ or ${ }^{3} \mathrm{H}-\mathrm{RU} 28362$ were separated on Sephadex LH-20 columns equilibrated with TEGDM buffer at $2^{\circ} \mathrm{C}$, using $60 \mu \mathrm{l}$ of the incubates eluted with $940 \mu \mathrm{l}$ of TEGDM buffer. One milliliter of the eluate containing the bound form was added to $3.5 \mathrm{ml}$ of scintillation fluid (Acqualuma, Lumac), and radioactivity was counted. Protein concentrations were determined according to Lowry (1951) using albumin as standard. The apparent maximum binding capacity $\left(B_{\max }\right)$ of ${ }^{3} \mathrm{H}-\mathrm{B}$ or ${ }^{3} \mathrm{H}-\mathrm{RU} 28362$ and dissociation constants $\left(K_{d}\right)$ for both types of receptors were evaluated from Scatchard plots (Scatchard, 1949).

\section{Procedures}

Experiment 1: influence of prenatal stress on corticosterone secretion and corticosteroid receptors of adult offspring. In this experiment we compared stress-induced corticosterone secretion and hippocampal corticosteroid receptors in prenatally stressed $(\mathrm{S} ; n=8)$ and control $(\mathrm{C} ; n=$ 9) rats raised by their biological mother. At $90 \mathrm{~d}$ of age, offspring of both groups were submitted to a $30 \mathrm{~min}$ restraint stress. Restraint was carried out in an identical plastic cylinder to that used for the prenatal stress. Corticosterone levels were determined in three blood samples $(250 \mu \mathrm{l})$ withdrawn from the tail vein. The three samples were collected before stress and 30 and $120 \mathrm{~min}$ afterward. Type I and type II corticosteroid receptor binding was measured 2 weeks later.

Experiment 2: interactions between adoption and prenatal stress. In this experiment, stress-induced corticosterone secretion and hippocampal corticosteroid receptors were studied in six groups of animals (Iable 1). The first two groups were identical to those in the previous experiment, and contained either control $(C ; n=7)$ or stressed $(S ; n=6)$ offspring raised by their biological mother. The third and the fourth groups contained either control or prenatally stressed rats that were raised by an adoptive foster mother of the same group. Thus, the third group contained prenatally unstressed offspring adopted by a control unstressed mother ( $\mathrm{CC} ; n=6)$, and the fourth group contained prenatally stressed offspring adopted by a stressed mother (SS; $n=6$ ). The last two groups contained offspring, either unstressed or stressed prenatally, that were adopted by mothers of opposite groups. Thus, one group contained prenatally unstressed rats raised by a stressed foster mother $(\mathrm{CS} ; n=5)$, while the other contained prenatally stressed rats adopted by an unstressed foster mother (SC; $n=5$ ). These groups were used to (1) replicate the study of the effects of prenatal stress, (2) study the effects of adoption per se and its influence on the effects of prenatal stress, and (3) control for the influence of the experiences of the foster mother on the outcomes of adoption.

In this experiment, exposure to novelty was the stress used to challenge corticosterone secretion in the adult offspring ( $90 \mathrm{~d}$ of age). The animals were implanted with intracardiac catheters. They were individually housed during the $6 \mathrm{~d}$ recovery period, and they were then placed for $120 \mathrm{~min}$ in the novel environment consisting of a circular corridor (170 $\mathrm{cm}$ long and $10 \mathrm{~cm}$ wide). Blood samples for corticosterone assay were withdrawn from the catheter immediately before exposure to novelty and $30 \mathrm{~min}$ and $120 \mathrm{~min}$ afterward. Hippocampal corticosteroid receptors were measured 2 weeks later.

Experiment 3: influence of adoption on maternal behavior. In this experiment, the maternal behavior of foster and biological mothers was evaluated ( $n=4$ per group). The adoption procedure was identical to that described above. This time, both foster and biological mothers were removed from their cages for $1 \mathrm{~min}$, and the pups were distributed around the cage. Maternal behavior was observed from the moment 


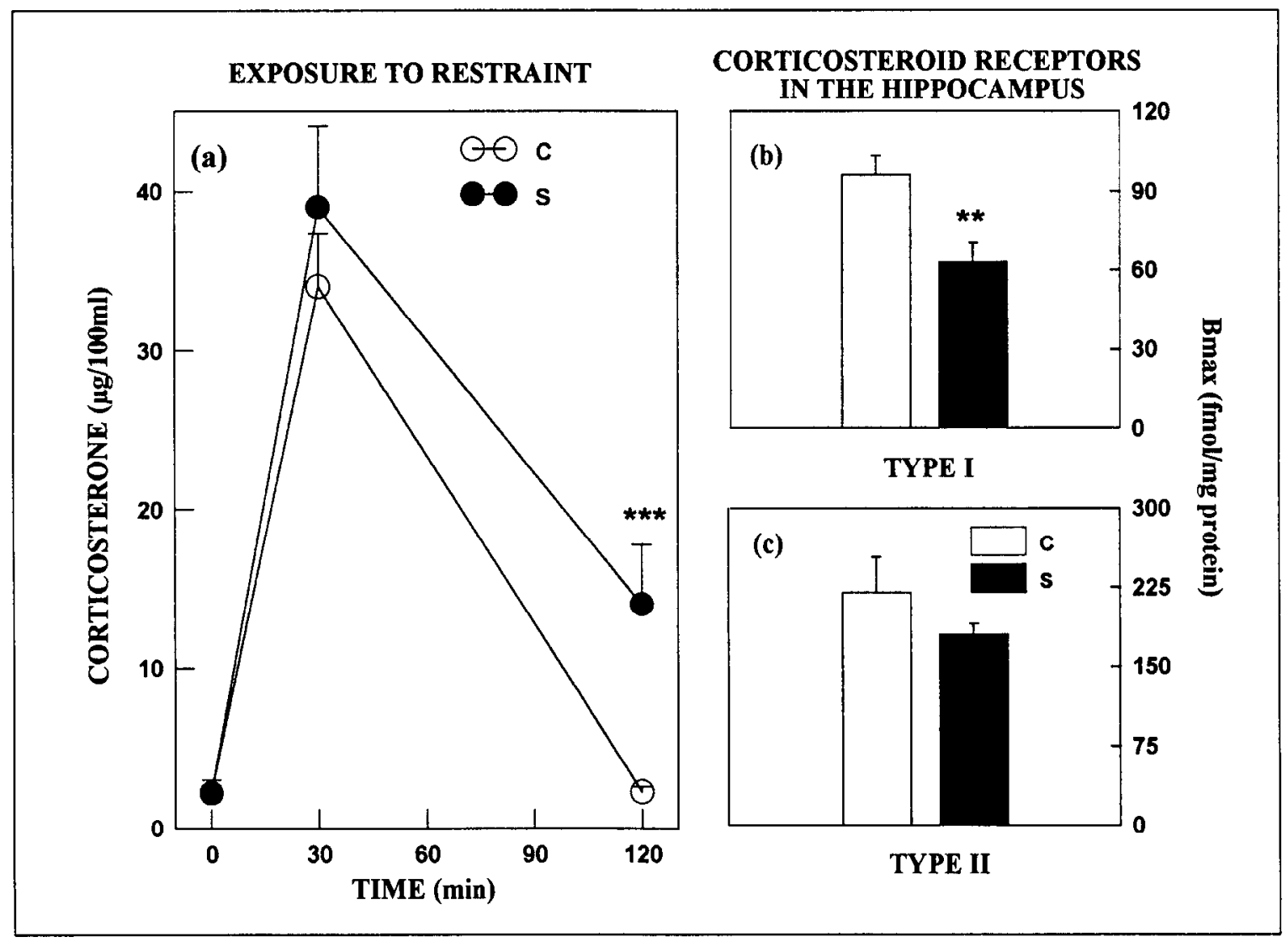

Figure 1. Plasma corticosterone secretion after restraint stress $(a)$ and type $\mathrm{I}(b)$ and type $\mathrm{II}(c)$ corticosteroid receptors in adult prenatally unstressed rats raised by their biological mother $(C)$ and adult prenatally stressed rats raised by their biological mother $(S)$. $a$, Prenatally stressed animals $(S)$ did not differ from controls $(C)$ for corticosterone levels in basal conditions or after 30 min exposure to restraint stress. However, corticosterone levels remained high in prenatally stressed rats $120 \mathrm{~min}$ after stress, whercas they returned to preceposure valucs in the controls. $b$, Prenatally stressed rats $(S)$ showed a lower binding capacity $(-40 \%)$ of type I corticosteroid receptors than controls $(C)$. $c$, Prenatal stress did not significantly modify type II corticosteroid receptors. The affinities of type I and type II receptors were not modified by prenatal stress. Mean affinities were, for type I, $1.14 \pm 0.11 \mathrm{nM}$; type II, $0.6 \pm 0.12 \mathrm{nM} .{ }^{* * *}, p<0.001 ;{ }^{* *}, p<0.01$. Error bars show SEM.

the mother was reintroduced into the cage. The two parameters recorded were (1) retrieval latency: time spent by the mother to pick up and to place each pup in the nest over $30 \mathrm{~min}$; (2) time of contact: measured by the time spent by the mother licking and picking up pups over 15 min. These parameters provide reliable information on maternal behavior and are widely used in studies on laboratory rats (Haney et al., 1989; Mann, 1993).

Statistics. The results were compared by two-way analysis of variance (ANOVA). A logarithmic transformation was applied if the data did not present a normal distribution (Bartlett's test). In the second experiment, the influence of stress and adoption and their interaction were evaluated by bifactorial analysis.

\section{Results}

Experiment 1. Prenatal stress: influences on stress-induced corticosterone secretion and hippocampal corticosteroid receptors. In adult rats, prenatal stress prolonged the corticosterone secretion induced by restraint stress [prenatal stress $\times$ time interaction: $F(2,30)=18.07 ; p<0.0001$ ] (Fig. 1a). Corticosterone levels in either basal conditions or 30 min after stress did not differ between the control and prenatally stressed rats. In contrast, two hours after stress, corticosterone secretion was higher in the prenatally stressed than in the control rats $[F(1,15)=$ 53.75; $p<0.0001]$. Prenatal stress also decreased hippocampal corticosteroid receptors $[F(1,15)=4.85 ; p=0.043]$. Type I receptors were reduced by $40 \%[F(1,15)=10.89 ; p=0.0050]$ (Fig. $1 b$ ), and type II receptors by $20 \%$ (NS) (Fig. 1c).
Experiment 2. Adoption: interaction with prenatal stress and intrinsic action. The results of this experiment confirmed and extended the results of the previous one. Thus, in adult prenatally stressed rats, stress-induced corticosterone secretion was prolonged [prenatal stress $\times$ time interaction: $F(2,42)=4.17$; $p=0.023$ ] (Fig. $2 a$ ) and there was a $60 \%$ reduction in number of hippocampal type I receptors $[F(1,21)=10.37 ; p=0.0041]$ (Fig. $2 b$ ). The number of type II corticosteroid receptors was also decreased (22\%) in the prenatally stressed animals, but not in a statistically significant manner (Fig. $2 c$ ).

Adoption at birth totally reversed the effects of prenatal stress on both corticosterone secretion [prenatal stress $\times$ adoption $\times$ time interaction: $F(2,42)=6.722 ; p=0.0033$ ] and hippocampal receptors [prenatal stress $\times$ adoption $\times$ receptors interaction: $F(1,21)=5.75 ; p=0.025]$. Thus, animals that were both prenatally stressed and adopted did not differ from controls in either corticosterone secretion $2 \mathrm{hr}$ after strcss (Fig. $2 a$ ) or type I corticosteroid receptors (Fig. 2b). The effects of adoption on prenatal stress were not influenced by the treatment received by the foster mother during pregnancy. Thus, adoption suppressed the effects of prenatal stress whether prenatally stressed rats were adopted by control unstressed (SC) or stressed mothers (SS) (Fig. 2a,b).

Adoption per se had no significant effect on either corticosteroid receptor numbers or duration of the corticosterone re- 


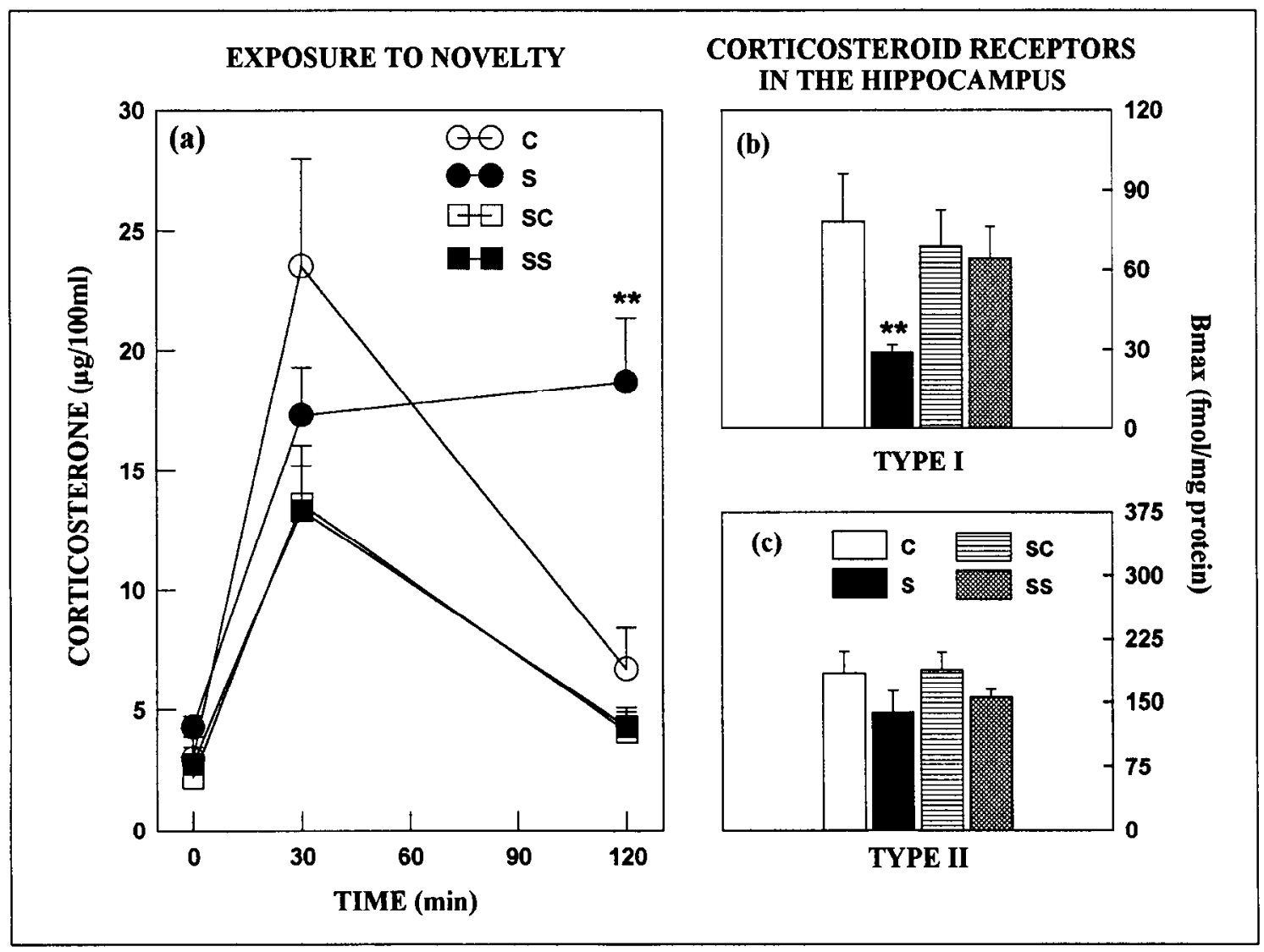

Figure 2. Plasma corticosterone secretion after novelty exposure $(a)$ and type I $(b)$ and type II (c) corticosteroid receptors in adult prenatally unstressed rats raised by their biological mother $(C)$, adult prenatally stressed rat raised by their biological mother $(S)$, adult prenatally stressed rats adopted by a control unstressed mother $(S C)$, and adult prenatally stressed rats adopted by a mother stressed during pregnancy ( $S S$ ). $a$, Prenatally stressed animals $(S)$ displayed higher corticosterone levels than those of control rats $(C)$ after 120 min of novelty exposure. Animals that were both stressed and adopted did not differ from controls, either if the adoptive mother was unstressed $(S C)$ or stressed $(S S)$ during pregnancy. $b$. Type I corticosteroid receptors were reduced by prenatal stress and this effect was totally reversed by adoption in both $S C$ and $S S$ groups. $c$, Neither prenatal stress nor adoption significantly modified type II corticosterone receptors. The affinities of type I or type II receptors were not influenced by any of the experimental conditions studied. ${ }^{* *}, p<0.01$ (prenatal stress vs control). Error bars show SEM.

sponse to stress (Fig. $3 a-c$ ). However, it did reduce stress-induced corticosterone secretion [adoption $\times$ time interaction: $F(2,42)=4.97 ; p=0.012$ ]. Although adopted and control rats did not differ in corticosterone levels under basal conditions or $120 \mathrm{~min}$ after stress, the corticosterone stress peak (30 min after exposure to novelty) was lower in the adopted rats than in the controls (Fig. $3 a$ ). This effect of adoption was not influenced by the treatment received by the foster mother during pregnancy. Thus, stress-induced corticosterone secretion in unstressed adopted rats was lower than controls $(C)$ after adoption by either a control unstressed mother (CC group) $[F(1,11)=6.19 ; p=$ $0.0378]$ or a stressed mother (CS) $[F(1,10)=6.01 ; p=0.0368]$.

Experiment 3: influence of adoption on maternal behavior. Adoption increased maternal behavior. Thus, foster mothers spent longer licking and picking up pups (contact time) than did the biological mothers $[F(1,6)=15.63 ; p<0.01]$ (Fig. $4 a$ ). The latency to replace all the pups in the nest (retrieval latency) was also lower with the foster than with the biological mothers $[F(1,6)=5.92 ; p=0.041]$ (Fig. 4b).

\section{Discussion}

Ours results indicate that prenatal and postnatal events have a long-term influence on the functional state of the HPA axis. Prenatal stress prolonged stress-induced corticosterone secre- tion, which was indicative of impaired corticosterone feedback, and selectively reduced type I corticosteroid receptors. In contrast, as described by other authors (Weinstock et al., 1992), prenatal stress failed to modify type II corticosteroid receptors. Adoption at birth totally reversed the effects of prenatal stress, although adoption per se did not modify either corticosteroid receptors or the duration of stress-induced corticosterone secretion. In fact, adoption per se reduced the stress-induced corticosterone secretion peak. The interaction of adoption with prenatal stress and the effects of adoption per se were not influenced by the treatment received by the adoptive mothers during pregnancy. Similar results were observed whether the foster mother was stressed or not during pregnancy. Adoption also enhanced maternal behavior as the foster mothers devoted more attention to the pups than did the biological mothers.

The decrease in hippocampal type I corticosteroid reccptors observed in prenatally stressed rats could account for their prolonged stress-induced corticosterone secretion. Central corticosteroid receptors are now thought to be a fundamental link in the chain of factors regulating corticosterone secretion (McEwen et al., 1986). Hippocampal corticosteroid receptors appear to play an important role in this process, as it has been shown that a selective reduction in hippocampal corticosteroid receptors is accompanied by a prolonged corticosterone secre- 


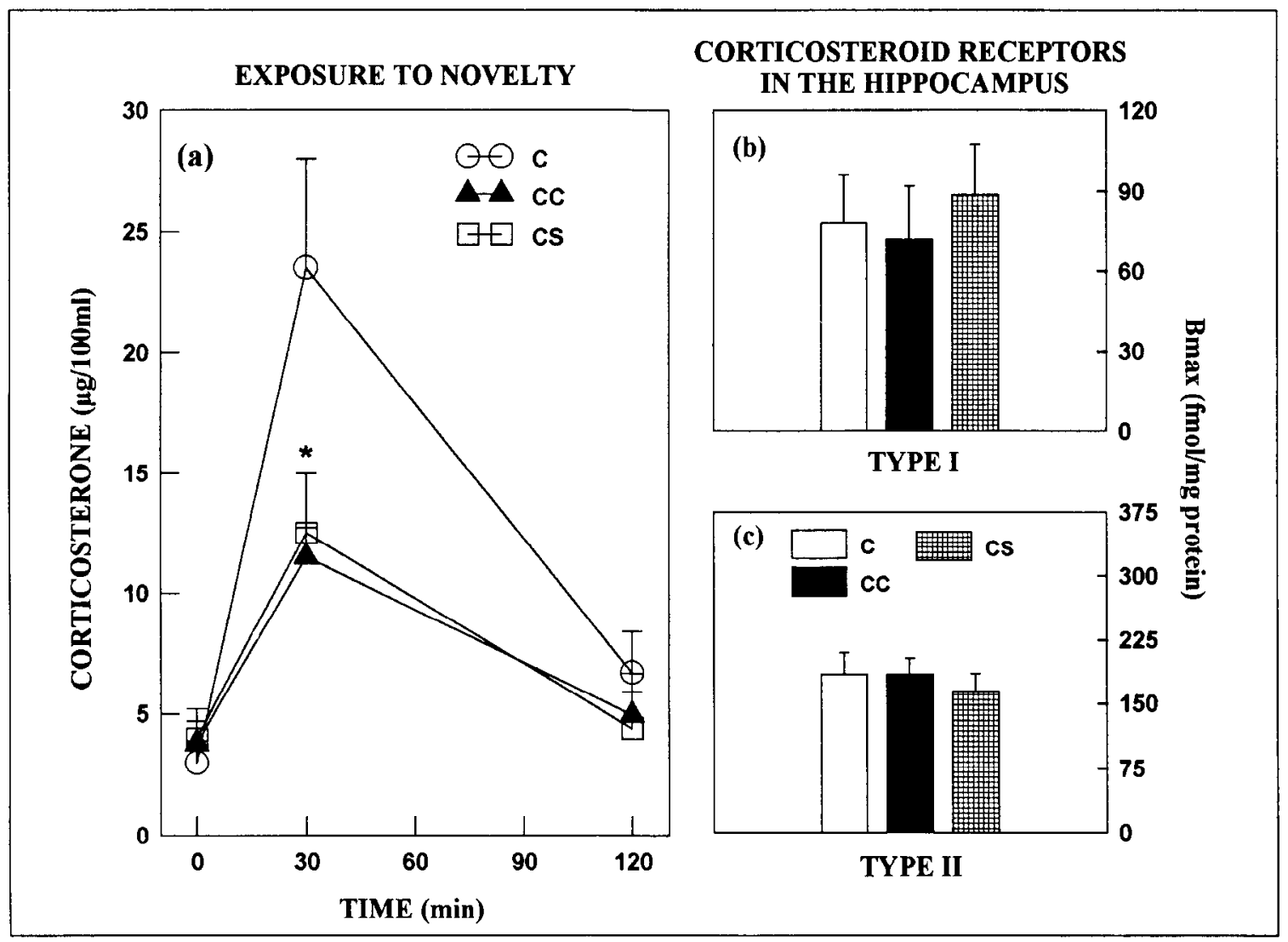

Figure 3. Plasma corticosterone secretion after novelty exposure $(a)$, type I $(b)$, and type II $(c)$ corticosteroid receptors in adult prenatally unstressed rats raised by their biological mother $(C)$, adult prenatally unstressed rats adopted by a control unstressed mother $(C C)$, and adult prenatally unstressed rats adopted by a mother stressed during pregnancy $(C S)$. $a$, Adopted animals, independently of the treatment received by the mother during pregnancy, had lower corticosterone levels after $30 \mathrm{~min}$ of exposure to novelty than control rats. $b$ and $c$, Adoption did not significantly modify type I or type II corticosteroid receptors. The affinities of type I or type II receptors were not influenced by any of the experimental conditions studied. ${ }^{*}, p<0.05$ (adopted groups vs control). Error bars show SEM.

tion in response to stress (McEwen et al., 1986; Sapolsky et al., 1986). This idea is also supported by two further observations. First, adoption, which suppressed the prolonged corticosterone secretion in prenatally stressed animals, also increased type I receptors in the hippocampus. Second, a selective reduction in type I hippocampal corticosteroid receptors has been found to be associated with a prolonged stress-induced corticosterone secretion, akin to that observed in prenatally stressed rats (Maccari et al., 1991).

Although the mechanism by which prenatal stress could reduce corticosterone receptors in the adult is unknown, several possibilities come to mind. For example, exposure in utero to abnormal levels of maternal corticosteroids, which do cross the placental and blood-brain barriers (Zarrow et al., 1970), may play a role. In the adult, chronic stress and repeated corticosterone administration have been found to reduce corticosteroid reccptor numbers (Sapolsky ct al., 1984a,b; Maccari ct al., 1991), whereas perinatal administration of corticosteroids has been found to have neurotoxic effects in the hippocampus (Uno et al., 1990). Prenatal stress may also modify glucocorticoid secretion in the adult by acting on the developing noradrenergic systems. This idea is supported by three lines of evidence. First, prenatal stress increases the turnover of brain noradrenergic neurons in adult rats (Takahashi et al., 1992). Second, norepinephrine exerts a direct inhibitory control on hippocampal cor- ticostcroid receptors and facilitatcs corticosterone secretion (Maccari et al., 1990, 1992a). Third, norepinephrine has more influence on type I than on type II receptors (Maccari et al., 1992a,b). The type II receptors appear to be more sensitive to changes in corticosterone levels (Reul et al., 1987).

The suppression of the prolonged corticosterone secretion in prenatally stressed rats by adoption may be accounted for its effects on type I hippocampal corticosteroid receptors. However, this mechanism cannot explain the decrease in corticosterone secretion peak induced by adoption per se. This is not altogether unexpected as changes in glucocorticoid receptors, which determine the efficiency of corticosterone feedback, are more commonly associated with changes in the duration rather than the amplitude of corticosterone secretion (Sapolsky et al., 1984b, Meaney et al., 1988; Maccari et al., 1991). Thus, adoption may modify corticosterone secretion via an action on the neurohormonal mechanisms involved in the secretive phase of HPA axis activity. In this respect, the effect of adoption per se on corticosterone secretion appears to differ from that of other postnatal stimulations. For example, postnatal handling selectively reduces the amplitude and the duration of stress-induced corticosterone secretion and increases type II corticosteroid receptors (Meaney et al., 1988). However, both adoption and postnatal handling converge in reducing glucocorticoid secretion, which may be a common effect of postnatal activation. 


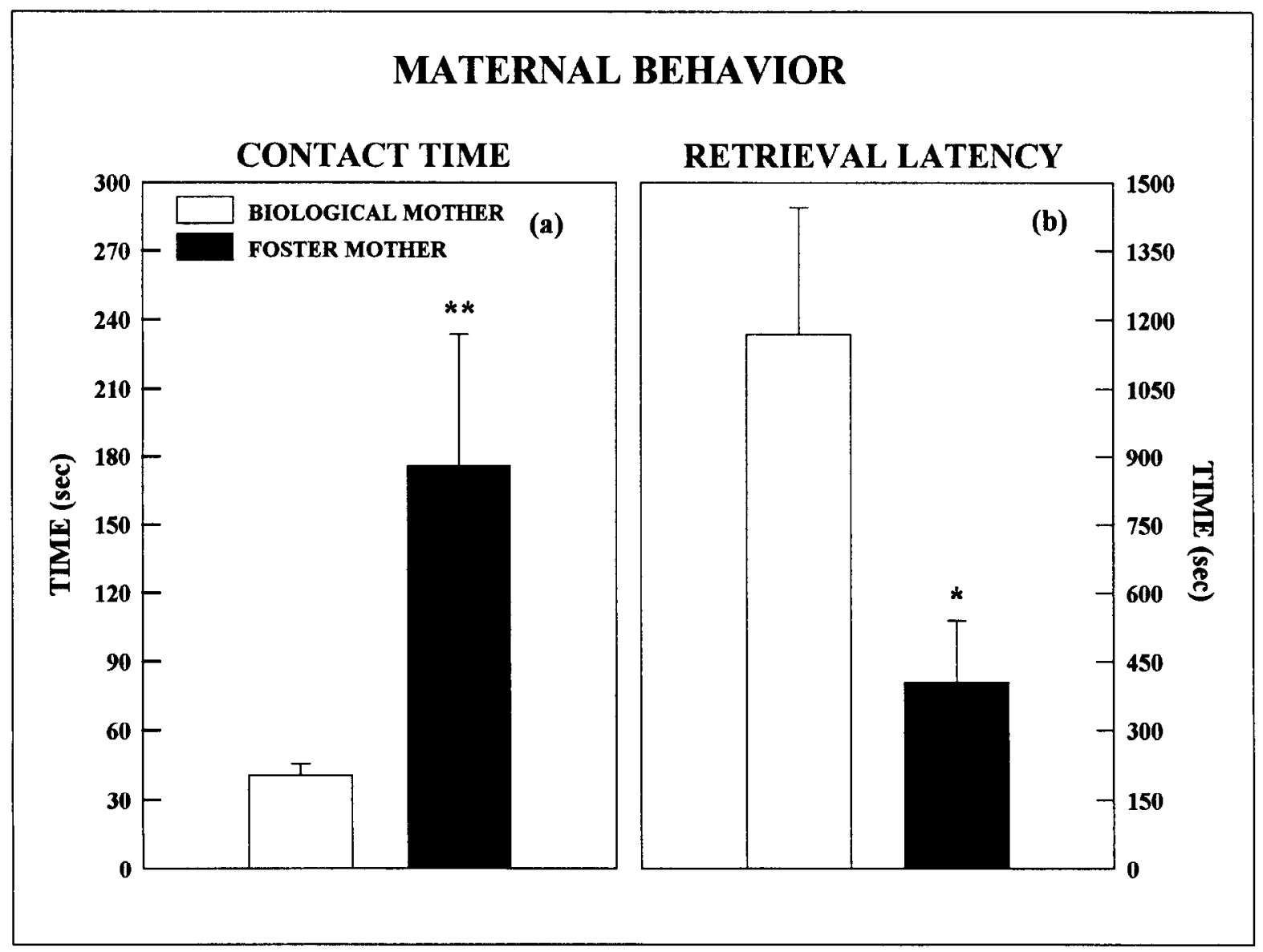

Figure 4. Effects of adoption on maternal behavior. $a$, Foster mothers spent longer licking and picking up the pups (contact time) than did biological mothers. $b$, Latency to replace all the pups in the nest (retrieval latency) was lower in foster than in adopted mothers. The time of observation was $15 \mathrm{~min}$ for the contact time and $30 \mathrm{~min}$ for the retrieval latency. ${ }^{*}, p<0.05 ;{ }^{* *}, p<0.01$. Error bars show SEM.

The exact mechanisms by which adoption in the postnatal period exercise its long-term effect on the functional state of the HPA axis remain to be elucidated. However, several hypotheses can be advanced. First, changes in maternal behavior can play a role, as we and others (Misanin et al., 1977) have found that foster mothers provide more maternal attention and stimulation to the pups than do the biological mothers. This mechanism has also been proposed to account for the long-term effects observed after other forms of neonatal stimulation (Bell et al., 1974; Hennessy et al., 1988). Second, changes in the hormonal status of the mother may be involved in the effects of adoption per se. Thus, it has been shown that an increase in maternal corticosterone levels, which can reach the pups through the milk (Angelucci et al., 1985), induces in adult offspring a comparably reduced stress-induced corticosterone secretion peak to that observed in adopted rats (Catalani et al., 1993). Third, adoption may reverse the effect of prenatal stress by a neuronal mechanism. For example, it has been shown that postnatal manipulations have a long-lasting effect on the activity of aminergic neurons (Mitchell et al., 1990), which in turn can modulate the binding capacity of corticosteroid receptors (Maccari et al., 1992a,b).

In conclusion, although the development of an organism carries a strong genetic component (Bouchard et al., 1990; Plomin, 1990), the early environment can have a long-lasting influence. Both prenatal and postnatal events may modify the activity of the HPA axis, albeit in opposite directions, and postnatal stimulation has been found to suppress the biological effects of prenatal stress. The recognized influence of the activity of the HPA axis on behavioral adaptation suggests that a modification of corticosterone secretion could be a biological substrate of the long-term behavioral effects of prenatal and postnatal events.

\section{References}

Angelucci L, Patacchioli FR, Scaccianoce S, Di Sciullo A, Cardillo A, Maccari S (1985) A model for later-life effects of perinatal drug exposure: maternal hormone mediation. Neurobehav Toxicol Teratol 7:511-517.

Arriza JL, Weinberger C, Cerelli G, Glaser TM, Handelin BL, Housman DE, Evans RM (1987) Cloning of human mineralocorticoid receptor complementary DNA: structural and functional kinship with the glucocorticoid receptor. Science 237:268-275.

Bell RW, Nitschke W, Bell NJ, Zachman TA (1974) Early experience, ultrasonic vocalisations, and maternal responsiveness in rats. Dev Psychobiol 7:235-242.

Bouchard TJ, Lykken DT, McGue M, Segal NL, Tellegen A (1990) Source of human psychological differences: the Minnesota study of twins rcarcd apart. Scicnce 250:223-228.

Casolini P, Piazza PV, Kabbaj M, Leprat F, Angelucci L, Simon H, Le Moal M (1993) The mesolimbic dopaminergic system exerts an inhibitory influence on brain corticosteroid receptor affinities. Neuroscience 55:429-434.

Catalani A, Marinelli M, Scaccianoce S, Nicolai R, Muscolo LAA, Porcu A, Koranyi L, Piazza PV, Angelucci L (1993) Progeny of mother drinking corticosterone during lactation has lower stress-induced cor- 
ticosterone secretion and better cognitive performance. Brain Res 624:209-215.

De Kloet ER, Reul JMHM (1987) Feedback action and tonic influence of corticosteroids on brain function: a concept arising from the heterogeneity of brain receptor systems. Psychoneuroendocrinology 12: 83-105.

Deminière JM, Piazza PV, Guegan G, Abrous N, Maccari S, Le Moal M, Simon H (1992) Increased locomotor response to novelty and propensity to intravenous amphetamine self-administration in adult offspring of stressed mothers. Brain Res 586:135-139.

Fride E, Dan Y, Feldon J, Halevy G, Weinstock M (1986) Effects of prenatal stress on vulnerability to stress in prepubertal and adult rats. Physiol Behav 37:681-687.

Hall RCW, Popkin MK, Stickney SK, Gardner ER (1979) Presentation of steroid psychoses. J Nerv Ment Dis 167:229-236.

Haney M, DeBold J, Miczek K (1989) Maternal aggression in mice and rats towards male and female conspecifics. Aggressive Behav 15: $443-453$.

Hennessy MB, Li Julia, Lowe EL, Levine S (1980) Maternal behavior, pup vocalisations, and pups temperature changes following handling in mice of 2 inbred strains. Dev Psychobiol 13:573-584.

Hollenberg SM, Weinberger C, Ong ES, Cerelli G, Oro A, Lebo R, Thompson EB, Rosenfeld MG, Evans RM (1985) Primary structure and expression of a human glucocorticoid receptor cDNA. Nature 318:635-641.

Holsboer F (1989) Psychiatric implications of altered limbic-hypothalamic-pituitary-adrenocortical activity. Eur Arch Psychiatr Neurol Sci 238:302-322

Kalimi M, Hubbard JR (1983) Development of an exchange assay for cytosolic glucocorticoid receptors using the synergistic effects of molybdate plus dithiothreitol. Endocrinology 113:1161-1163.

Levine S (1962) Plasma-free corticosteroid response to electric shock in rats stimulated in infancy. Science 135:795-796.

Ling MHM, Perry PJ, Tsuang MT (1981) Side effects of corticosteroid therapy. Arch Gen Psychiatry 38:471-477.

Lowry OH, Rosenbough N, Farr AL, Randall RJ (1951) Protein measurements with the Folin phenol reagent. J Biol Chem 193:265-267.

Maccari S, Le Moal M, Angelucci L, Mormède P (1990) Influence of 6-OHDA lesion of central noradrenergic systems on corticosteroid receptors and neuroendocrine responses to stress. Brain Res 533:6065.

Maccari S, Piazza PV, Deminière JM, Lemaire V, Mormède P, Simon H, Angelucci L, Le Moal M (1991) Life events-induced decrease of type I corticosteroid receptors is associated with a decrease of corticosterone feedback and increase the vulnerability to amphetamine self-administration. Brain Res 547:7-12.

Maccari S, Mormède P, Piazza PV, Simon H, Angelucci L, Le Moal M (1992a) Hippocampal type I and type II corticosteroid receptors are modulated by central noradrenergic systems. Psychoneuroendocrinology 17:103-112.

Maccari S, Piazza PV, Rouge-Pont F, Angelucci L, Simon H, Le Moal M (1992b) Noradrenergic regulation of type I and type II corticosteroid receptors in amygdala and hypothalamus. Brain Res 587:313318.

Mann PE (1993) Measurement of maternal behavior. Methods Neurosci 14:343-358.

McEwen BS, De Kloet ER, Rostène W (1986) Adrenal steroid receptors and actions in the nervous system. Physiol Rev 66:1121-1188.

Meaney MJ, Aitken DH, Van Berkel C, Bhatnagar S, Sapolsky M (1988a) Effect of neonatal handling on age-related impairments associated with the hippocampus. Science 239:766-768.

Meaney MJ, Viau V, Aitken DH, Bhatnagar S (1988b) Stress-induced occupancy and translocation of hippocampal glucocorticoid receptors. Brain Res 445:198-203.

Misanin JR, Zawacki DM, Krieger WG (1977) Differential maternal behavior of the rat dam toward natural and foster pups: implication for nutrition research. Bull Psychonom Soc 10:313-316.

Mitchell JB, Iny LJ, Meaney MJ (1990) The role of serotonin in the development and environmental regulation of hippocampal type II corticosteroid receptor binding. Dev Brain Res 55:231-235.

Murphy BEP (1967) Some studies of the protein binding of steroids and their application to the routine micro- and ultramicro-measurement of various steroids in body fluids by competitive protein-binding radioassay. J Clin Endocrinol Metab 27:973-990.

Pepper GM, Krieger DT (1984) In: Neurobiology of mood disorders (Post RM, Ballenger JC, eds), pp 245-254. Baltimore: Williams and Wilkins.

Persky H (1975) Adrenocortical function and anxiety. Psychoneuroendocrinology 1:37-44.

Peters DAV (1982) Prenatal stress: effects on brain biogenic amine and plasma corticosterone levels. Pharmacol Biochem Behav 17:721725.

Piazza PV, Maccari S, Deminière JM, Le Moal M, Mormède $P$, Simon H (1991) Corticostcrone levels determinc individual vulnerability to amphetamine self-administration. Proc Natl Acad Sci USA 88: 2088-2092.

Plomin R (1990) The role of inheritance in behavior. Science 248: 183-188.

Ratka A, Sutanto W, Bloemers M, de Kloet R (1989) On the role of brain mineralocorticoid (type I) and glucocorticoid (type II) receptors in neuroendocrine regulation. Neuroendocrinology 50:117-123.

Reul JMHM, De Kloet ER (1985) Two receptor systems for corticosterone in rat brain: microdistribution and differential occupation. Endocrinology 117:2505-2511.

Reul JMHM, Van Den Bosch FR, De Kloet ER (1987) Differential response of type I and type II corticosteroid receptors to changes in plasma steroid level and circadian rhythmicity. Neuroendocrinology 45:407-412.

Sapolsky RM, Krey LC, McEwen BS (1984a) Glucocorticoid-sensitive hippocampal neurons are involved in terminating the adrenocortical stress response. Proc Natl Acad Sci USA 81:6174-6177.

Sapolsky RM, Krey LC, McEwen BS (1984b) Stress down-regulates corticosterone receptors in a site-specific manner in the brain. Endocrinology 114:287-292.

Sapolsky RM, Krey LC, McEwen BS (1986) The neuroendocrinology of stress and aging: the glucocorticoid cascade hypothesis. Endocr Rev 7:284-301.

Scatchard G (1949) The attraction of proteins for small molecules and ions. Ann NY Acad Sci 51:660.

Shell LM (1981) Environmental noise and human prenatal growth. Am J Physiol Anthropol 56:63-70.

Stott DN (1973) Follow-up study from birth of the effects of prenatal stress. Dev Med Child Neurol 15:770-787.

Takahashi LK, Kalin NH, Barksdale CM, Van Der Burgt JA (1988) Stressor controllability during pregnancy influences pituitary-adrenal hormone concentrations and analgesic responsiveness in offspring. Physiol Behav 42:323-329.

Takahashi LK, Turner JG, Kalin NH (1992) Prenatal stress alters brain catecholaminergic activity and potentiates stress-induced behavior in adult rats. Brain Res 574:131-137.

Thompson WR (1957) Influence of prenatal maternal anxiety on emotionality in young rats. Science 125:698-699.

Uno H, Long L, Thieme C, Kemnitz JW, Engle MJ, Roecker EB, Farrell PM (1990) Brain damage induced by prenatal exposure to dexamethasone in fetal rhesus macaques. I. Hippocampus. Dev Brain Res 53:157-167.

Wakshlak A, Weinstock M (1990) Neonatal handling reverses behavioral abnormalities induced in rats by prenatal stress. Physiol Behav 48:289-292.

Ward IL, Weisz J (1984) Differential effects of maternal stress on circulating levels of corticosterone, progesterone and testosterone in male and female rat fetus and their mothers. Endocrinology 84:11451135 .

Weinstock M, Fride E, Hertzberg R (1988) Prenatal stress effects on functional development of the offspring. Prog Brain Res 73:319-331.

Weinstock M, Matlina E, Maor GI, Rosen H, McEwen B (1992) Prenatal stress selectively alters the reactivity of the hypothalamic-pituitary adrenal system in the female rat. Brain Res 595:195-198.

Zarrow MX, Philpott JE, Denenberg VH (1970) Passage of 14C-4 corticosterone from the rat mother to the foetus and neonate. Nature 226:1058-1059. 